\title{
Mısırlı Kârîlerin Mücevved Tilâvetlerinin Metro-Ritmik Karakteri
}

\section{The Metro-Rhythmic Character of Mujawwad Recitations of the Egyptian Reciters}

\author{
Dr. Muhammed Recai ÇÍFTÇİ \\ Diyanet İşleri Başkanlı̆̆g \\ Dr., Presidency of Religious Affairs, Ankara, Turkey. \\ muhammedrecai@gmail.com
}

(iD) 0000-0003-0915-982X

Makale Bilgisi / Article Information

Makale Türü / Article Type Araştırma Makalesi / Research Article

Geliş Tarihi / Received

Kabul Tarihi / Accepted

Yayın Tarihi / Published

23 Mayis / May 2021

28 Ağustos / August 2021

23 Eylül / September 2021

Atıf Bilgisi / Cite as:

Çiftçi, Muhammed Recai. “Mısırlı Kârîlerin Mücevved Tilâvetlerinin Metro-Ritmik Karakteri”, Eskişehir Osmangazi Üniversitesi İlahiyat Fakültesi Dergisi 8/2 (Eylül 2021), 112-132.

http://doi.org/1051702/esoguifd.941226

Intihal / Plagiarism: Bu makale, en az iki hakem tarafından incelenmiş ve intihal içermediği teyit edilmiştir. / This article has been reviewed by least two referees and scanned via a plagiarism software.

Copyright (c) Published by Eskişehir Osmangazi Üniversitesi, İlahiyat Fakültesi /Eskişehir Osmangazi University, Faculty of Theology Bütün hakları saklıdır. / All right reserved. https://dergipark.org.tr/tr/pub/esoguifd

CC BY-NC 4.0 This paper is licensed under a Creative Commons Attribution-NonCommercial License

Etik Beyanı / Ethical Statement: Bu çalışmanın hazırlanma sürecinde bilimsel ve etik ilkelere uyulduğu, yararlanılan tüm çalışmaların kaynakçada belirtildiği ve bu araştırmanın desteklenmesi için herhangi bir dış fon almadıkları yazar tarafından beyan olunur / It is declared by the author that scientific and ethical principles have been followed while carrying out and writing this study; that all the sources used have been properly cited; that no external funding was received in support of the research. 


\section{Mısırlı Kârîlerin Mücevved Tilâvetlerinin Metro-Ritmik Karakteri}

Öz Mısır, İslam dünyasında Kur'an tilâveti için dikkate değer ve seçkin bir merkez konumunda bulunmaktadır. Bu coğrafyada yetişen kudretli okuyucuların bütün dünyada şöhret kazandığı görülmektedir. Abdüssamed, Husarî, Minşâvî, Muhammed Rif at, Mustafa İsmâil ve Şa şâî gibi isimlerin de arasında bulunduğu kârîlerin tilâvetleri, özellikle 20. yüzyılın ikinci yarısında daha çok radyo ve kaset gibi teknolojilerle dünya müslümanlarına ulaşma imkanı bulmuştur. Mısırlı okuyucuların okuyuşları, hız karakteri, melodik yapı ve sunum gibi ön plana çıkan bazı dinamiklere bağlı olarak iki kategoride şekillenmektedir. Murattel ve mücevved olarak isimlendirilen bu okuyuşların sunum ve melodik yapı gibi özellikleri batıdaki çeşitli araştırmalarda analiz edilmiş olsa da, zamansal ve metro-ritmik özelliklerinin inceleme konusu yapılmadığı anlaşılmaktadır. Mücevved okuyuşların analiz edileceği bu araştırmanın amacı, öncelikle Mısır'da iki kategoride şekillenen okuyuşlar arasında etraflı bir karşılaştırma yapılmasına imkan tanıyacak ön adımları atmak, daha sonra da bu okuyuşlarla ülkemizdeki okuyuşların benzeșen ve ayrışan yönlerinin ortaya konulmasına imkan tanımaktır. Bu araştırmada Abdüssamed, Husarî, Minşâvî, Muhammed Rif' at, Mustafa İsmâil ve Şa ‘şâ̂̀nin Fâtiha sûresi okuyuşları analiz edilmiştir. Elde edilen veriler değerlendirildiğinde okuyuşların büyük oranda benzeştiği ortaya çıkmıştır.

Anahtar Kelimeler: Türk Din Musikisi, Mısır, Kur'an, Mücevved, Seyir, Metro-Ritmik.

\section{The Metro-Rhythmic Character of Mujawwad Recitations of the Egyptian Reciters}

Abstract It is a remarkable and distinguished center for Qur'an recitation in the Islamic world of Egypt. It is seen that powerful reciters who grew up in this geography gained fame all over the world. Especially in the second half of the 20th century, the recitings of the reciters, including names such as Abdüssamed, Husari, Minşâvî, Muhammed Rif'at, Mustafa İsmâil and Şa şâ̂i, had the opportunity to reach Muslims of the world with technologies such as radio and cassettes. The recitings of the Egyptian reciters is shaped in two categories, depending on some dynamics that come to the fore, such as the tempo, melodic structure and presentation. Although the features such as presentation and melodic structure of these recitings, which are named as morattal and mujawwad, had been analyzed in various studies in the west, it is understood that their temporal and metro-rhythmic properties were not subject to examination. The purpose of this study, in which mujawwad recitings will be analyzed, is to first take the preliminary steps that will allow a comprehensive comparison between the recitings shaped in two categories in Egypt, and then to reveal the similar and divergent features of the recitings in our country with these recitings. In this research, the recitings of Abdüssamed, Husari, Minşâvî, Muhammed Rif'at, Mustafa İsmâil and Şa şâ̂i Surah al-Fatiha were analyzed. When the data obtained were evaluated, it was revealed that the readings were mostly similar.

Keywords: Turkish Religious Music, Egypt, Qur'an, Mujawwad, Tempo, Metro-Rhythmic.

\section{Giriş}

Mısır, özellikle 20. yüzyılın son yarısıyla birlikte Kur'an tilâveti konusunda bütün müslümanlar için büyük öneme sahip bir ülke haline gelmiştir. Bu coğrafyada yetişen kârîlerin kendine has tarzları ile gerçekleştirmiş oldukları Kur'an tilâvetleri önceleri radyo yayınları ile kitlelere ulaşmakta iken, sonraları ise her dinleyicinin münferit bir yayıncı olmasına imkan sağlayan kaset teknolojisi ile kalıcı bir ulaşılabilirlik kazanmıştır. 21. yüzyılın başlarına gelindiğinde, dijitalleşen 
Çiftçi, Mısırl Kârîlerin Mücevved Tilâvetlerinin Metro-Ritmik Karakteri

dünyanın insanlığa sunduğu imkanlara paralel olarak dünyanın herhangi bir yerindeki Kur'an okuyuşuna müslümanların anlık ulaşma imkanına sahip olduğu görülmektedir.

Bir devlet politikası olarak da tanıtılıp yaygınlaştırılmasına önem verildiği anlaşılan Mısırlı okuyucuların kendine has Kur'an tilâvet modellerinin, okuyucuların İslam ülkelerine yaptıkları seyahatlerle de şöhret kazandığı anlaşılmaktadır.

Mısır'da murattel ve mücevved olmak üzere iki tür okuyuş modelinin geçerli ve uygulanabilir olduğu görülmektedir. Namaz ibadetinde ve pedagojik yönüyle Kur'an'ın eğitim süreçlerinde yer bulan murattel okuyuş, melodik açıdan sadeliği, tempo düzeyi itibariyle de hızlı karakteri ile ön plana çıkmaktadır.

Mücevved okuyuş biçiminin en belirgin tarafı ise hız özelliklerinin oldukça ağır bir karakter taşıması ile zengin ve ağdalı bir müziksel icra alanına yer açmasıdır. Bunun yanında hem cümlelerin hem de duraklamaların daha uzun tutulması göze çarpar. Melizmatik melodilere yer verilir. Buna karşıllk metinsel netliğin zayıflayabildiği görülür. Öğrenim süreçlerinde kullanıma uygun değildir. Seyirdeki yavaşlık, sesi karmaşıklaştıran slayt ve tril gibi çeşitli ses süslemelerine imkan tanır. ${ }^{1}$ Müzik/makam bilgisinin yanında etkili doğaçlama becerilerini gerektiren bir stil olarak göze çarpar. Tekrarlamaların büyük yer bulduğu bu okuyuş modelinde dinleyicilerden de geri dönüşler görülür. Okuyucu ile dinleyiciler arasındaki sıcak iletişim ve etkileşim bu modelde ön plana çıkmaktadır.

Mısır'ın Kur'an tilâvet kültüründeki canlılık, mücevved okuyuş modeli üzerinden okunabilmektedir. Kârîlerin okuyuşları, dinleyiciler tarafından ellerinde tuttukları bir kayıt cihazı ile kaydedilmekte ${ }^{2}$, dinleyicilerin tilâvetten etkilendiklerini gösteren bariz jestleri rahatlıkla gözlemlenebilmektedir. ${ }^{3} \mathrm{Bu}$ ortamda, dinleyicilerin okuyucuya seslenerek çeşitli isteklerde bulundukları anlaşılmaktadır.

“'Bir daha, ki ezberleyelim!', 'Daha yüksek perdeden!', 'Ey Nil'in bülbülü', 'Bize Şûri ver!', 'Harika okudun', 'Allahu Ekber', 'Saba (makamı)! Peygamber hakkı için, sabâ bekliyoruz!' gibi ifadelerle dinleyiciler beklentilerini ifade ederler. Okuyucu başka hafızlara müzikal göndermeler yaptığında bilgili dinleyiciler kendisine gönderme yapılan hafızın adını büyük bir hazla bağırarak, 'Bizi otuz yıl öncesine götürdü!' gibi yorumlarda bulunur. Dinleyicilerin sevdiği ya da istediği belli makamlarda kalmak ya da başka makamlara geçmek gibi konularda hafızların, dinleyicilerin yol göstericiliğine güvendikleri anlaşılmaktadır. Dinleyicilere yanıt veren, onları yol gösterici ve esin

\footnotetext{
${ }^{1}$ Kristina Nelson, The Art of Reciting the Qur'an (Cairo: American University in Cairo Press, 2001), 132; Lois Ibsen alFaruqi, “The Cantillation of the Qur'an”, Asian Music 19/1 (1987), 9-10; Michael Anthony Sells, Approaching the Qur'an: The Early Revelations (Ashland, Or: White Cloud Press, 2007), 163.

${ }^{2}$ Nelson, The Art of Reciting the Qur'an, xxvii.

${ }^{3}$ Ali Jihad Racy, Arap Dünyasında Müzik: Tarab Kültürü ve Sanatı, çev. Serdar Aygün (İstanbul: Ayrıntı, 2007), 145.
} 
kaynağı olarak kabul eden hafızların müzikal aktarımlarının daha etkileyici olduğu ifade edilmektedir." ${ }^{4}$

Müslüman toplumlardaki tilavet kültüründe görülen bu canlılıkta, İslam'ın Kur'an'ı güzel okumayı teşvik etmesinin çok önemli bir rolünün olduğu düşünülebilir. "Kur'an'ı seslerinizle süsleyiniz”, "Allah, hiçbir şeyi, bir peygamberin Kur'an'ı açıktan, güzel sesiyle okumasını dinlediği kadar dinlemedi”, "Kur' an'la teğanni etmeyen bizden değildir” şeklinde rivayet edilen ve ülkemizde Kur'an ve müzik ilişkisinden bahseden çeşitli çalışmalarda ${ }^{5}$ da ortaya konulan hadislerden ${ }^{6}$ okuyuşta müzikselliğin -en basit şekliyle dahi olsa- bulunmasının teşvik edildiği anlaşılmaktadır. Hadislerle ifade edilmiş olan bu teşvik çerçevesinde de Müslümanların bugün Kur'an'ı makamsal olarak en iyi ve etkili şekilde okumaya gayret ettiği söylenebilir.

Kur'an okurken güzel sesle okumanın önemi hadislerle ortaya konulmakla birlikte, Kur'an'ın sadece bir müziksel icra metni olmadığ ${ }^{7}$ da bütün Müslümanların üzerinde ittifak ettikleri bir konudur. Kur'an tilaveti ile müzikselliğin buluşmasının dinî duygu ve duyarlılığı diri tutan bir yönü olduğu, yaygın bir kanaat olarak karşımıza çıkmaktadır. Tilavet ile müzikselliği bir araya getirme noktasında, okuyucuların ilahî metindeki ahenk ve estetiği daha iyi ortaya koymaya gayret ettikleri de düşünülebilir.

$\mathrm{Bu}$ çalışmanın, ülkemizdeki bazı araştırmacılarca ortaya konulan Kur'an'ın fonetik i'cazı konusuna da bir yönüyle temas edebileceği ifade edilmelidir. Söz konusu araştırmalarda Kur'an'ın metin yapısının ve bu yapıyı oluşturan bir takım iç dinamiklerin Kur'an'a özgü bir müzikalite oluşturduklarından bahsedilmektedir. ${ }^{8}$ Kur'an harflerinin yapısal ve niteliksel olarak zengin ve renkli bir fonetiğe sahip olduğu, aynı vokallerin (harekelerin) art arda sıralanmasıyla bir ses uyumunun meydana geldiği, belirli sûrelerde bazı harflerin sıklıkla tekrarlanarak bir ritim oluşturulduğu gibi bir takım yargılar bu araştırmalarda yer almaktadır.

Kur'an ve müzik ilişkisine dair dünya literatürü incelendiğinde çok büyük oranda batılı araştırmacıların kısmen ele almaya çalıştığı ve genel olarak Arap ülkelerinde yetişen kârîlerin tilâvetlerini konu edinen araştırmaların, daha çok Kur'an tilâvetlerinin müziksel ve sosyo-kültürel

\footnotetext{
${ }^{4}$ Nelson, The Art of Reciting the Qur'an, 165; Kristina Nelson, "Reciter and Listener: Some Factors Shaping the Mujawwad Style of Qur'anic Reciting”, Ethnomusicology 26/1 (1982), 43.

${ }^{5}$ Necdet Çağıl, Kur'an Belagati ve Fonetiği Yönünden Kiraatler (Erzurum: Atatürk Üniversitesi, Sosyal Bilimler Enstitüsü, Doktora Tezi, 2002); Muhammet Yılmaz, "Muhammed Ebû Zehre'ye Göre Kur'an'ın Teğannî ile Okunuşu", Recep Tayyip Erdoğan Üniversitesi İlahiyat Fakültesi Dergisi 18 (2020), 93-111; Abdülmecit Okçu, "Kur’an Tilavetinde Ezgi", Dinî Araştırmalar 10/28 (2007), 213-247.

${ }^{6}$ Ebû Abdillâh Muhammed b. İsmail el-Buhârî, el-Câmi'u'ṣ-șahịh, nşr. Mustafa Dib el-Buga (b.y.: Daru İbn Kesir, 1407/1987), “Fezailü'l-Kur'an”, 19, “Tevhîd”, 32, 44, 52.

${ }^{7}$ Turan Koç, İslam Estetiği (İstanbul: İsam Yayınları, 2009), 174.

${ }^{8}$ Alican Dağdeviren, “Kur'an'ın Fonetik İ'cazı”, Sakarya Üniversitesi İlahiyat Fakültesi Dergisi 20/2 (2009), 71-78.
} 
Çiftçi, Mısırlı Kârîlerin Mücevved Tilâvetlerinin Metro-Ritmik Karakteri

yönüyle ilgilendikleri görülebilir. ${ }^{9}$ Ancak okuyuşta farklı stillere imkan tanıyan başat dinamik olarak gördüğümüz zamansal ve metrik karaktere dair literatürde herhangi bir araştırmaya rastlanmamaktadır.

Bu araştırmada Mısırlı okuyucuların Kur'an tilâvetlerinde kullandıkları mücevved adlı okuyuş modelinin zamansal ve metrik karakteri ele alınmaktadır.

\section{Araştırmanın Amaç ve Metodolojisi}

Kur'an'ın metro-ritmik özelliklerini analiz ettiğimiz, birbirinin devamı niteliğinde bir dizi olarak yayınlamayı sürdürdüğümüz bu gibi araştırmaların amacı, tavır kavramının "efrâdını câmî ağyârını mânî" bir tanımına imkan sağlayacak adımları atmaktır. Bu kavramın müzik ve kıraat gibi birbiri ile yakın ilişkisi bulunan disiplinlerde melodik yapı ve fonetik gibi okuyuş unsurlarına atıfta bulunularak kullanıldığı görülmektedir. Bununla birlikte bu unsurların tavır kavramını karşılamakta yetersiz kalabileceği düşünülmektedir. Bu noktada hem ülkemizdeki hem de diğer tilâvet merkezlerindeki okuyuşların analiz edilmesi, ortaya çıkan sonuçların karşılaştırılması, böylelikle okuyuştaki metro-ritmik özelliklerin tilâvet kültürleri arasında ayırt edicilik özelliklerine sahip olup olmadığının ortaya konulması önem taşımaktadır.

$\mathrm{Bu}$ araştırmaların tamamı hacimli bir karaktere sahip olmasından dolayı bir dizi olarak hazırlanmaktadır. Mücevved ile murattel okuyuşların yanında, ülkemizdeki Kur'an okuyuş biçimleri olan tahkik, tedvir ve hadr ayrı birer çalışmanın konusu olarak belirlenmiştir.

\subsection{Problem Durumu}

Mısır, Kur'an tilâvetinde dünya maüslümanlarının büyük bir beğeni ile takip ettiği

\footnotetext{
9 Lauren Osborne, “Textual and Paratextual Meaning in the Recited Qur'an: Analysis of a Performance of Surat alFurqan by Sheikh Mishary bin Rashid al-Afasy", Qur'anic Studies Today, ed. Angelika Neuwirth and Michael Sells (New York: Routledge, 2016), 228-246; Kristina Nelson, The Art of Reciting the Qur'an (Cairo: American University in Cairo Press, 2001); Michael Frishkopf, “Mediated Qur'anic Recitation and the Contestation of Islam in Contemporary Egypt", Music and the Play of Power in the Middle East, North Africa and Central Asia, ed. Laudan Nooshin (Farnham, Surrey: Ashgate, 2009); William A Graham - Navid Kermani, "Recitation and Aesthetic Reception", The Cambridge Companion to the Qur'ān, ed. Jane Dammen McAuliffe (Cambridge: Cambridge University Press, 2006); Józef M. Pacholczyk, Regulative principles in the Koran chant of Shaikh 'Abdu'l-Basit 'Abdu's Samad (Los Angeles: University of California, 1970). $\mathrm{Bu}$ çalışmaların birkaç basit hatayı içerdikleri de ifade edilmelidir. Munfasıl ve muttasıl medlerin birbirine karıştııılması, ayetlerdeki CV kalıbındaki hecelerin CVV, CVV kalıbındaki hecelerin CV olarak belirtilmesi ve ayetlerdeki bazı kelimelerin yanlış yazılması en bariz hatalara örnek verilebilir.
} 
okuyucuların yetiştiği önemli bir merkezdir. Abdüssamed ${ }^{10}$, Husarî ${ }^{11}$, Minşâ̂îi ${ }^{12}$, Muhammed Rif at ${ }^{13}$, Mustafa İsmâil ${ }^{14}$ ve Şa ${ }^{\text {şầ1 }}{ }^{15}$ bu okuyuculardan bazıları olarak zikredilebilir. Okuyuşlarında murattel ve mücevved olmak üzere iki tür seyir kullanan bu okuyucuların esas şöhret kazandıkları seyir biçimi olan mücevved okuyuş çerçevesinde, tilâvetleri metro-ritmik açıdan ele alan bir araştırma bulunmamaktadır.

\subsection{Problem Cümlesi}

Mısırlı kârîlerin mücevved seyrinde gerçekleştirdikleri okuyuşların zamansal özellikleri nelerdir?

\subsection{Hipotez}

Mısırlı kârîlerin mücevved seyrindeki okuyuşları karşılaştırmalı olarak analiz edildiğinde zamansal ve metrik özelliklerinin benzeştiği görülür.

\subsection{Alt Problem Soruları}

1.4.1. Abdüssamed'in okuyuşunun ${ }^{16} \mathrm{CV}$ birim süre ortalaması ve uzun hece-kısa hece oranı nedir?

1.4.2. Husarînnin okuyuşunun ${ }^{17} \mathrm{CV}$ birim süre ortalaması ve uzun hece-kısa hece oranı nedir?

1.4.3. Minşâvî̀nin okuyuşunun ${ }^{18} \mathrm{CV}$ birim süre ortalaması ve uzun hece-kısa hece oranı nedir?

1.4.4. Muhammed Rif'at'in okuyuşunun ${ }^{19} \mathrm{CV}$ birim süre ortalaması ve uzun hece-kısa hece

10 Ahmet Özel, “Abdülbâsit Muhammed Abdüssamed”, Türkiye Diyanet Vakfi İslâm Ansiklopedisi (Ankara: TDV Yayınları, 1988), 1/300.

11 Muhammed Mahmud Halil El-Husari, "Mahmûd Halîl Husarî”, Türkiye Diyanet Vakfi İslâm Ansiklopedisi (Ankara: TDV Yayınları, 1998), 18/412-413.

12 Saîd Murâd, "Muhammed Sıddîk Minşâvî”, Türkiye Diyanet Vakfi İslâm Ansiklopedisi (Ankara: TDV Yayınları, 2005), 30/117.

13 Saîd Murâd, "Muhammed Rif at”, Türkiye Diyanet Vakfi İslâm Ansiklopedisi (Ankara: TDV Yayınları, 2005), 30/566567.

${ }^{14}$ Saîd Murâd, “Mustafa İsmâil”, Türkiye Diyanet Vakfi İslâm Ansiklopedisi (Ankara: TDV Yayınları, 2006), 31/303-304.

${ }^{15}$ Saîd Murâd, "Şa'şâ̂̂”, Türkiye Diyanet Vakfi İslâm Ansiklopedisi (Ankara: TDV Yayınları, 2010), 38/367.

16 Huzur veren Sesler, "Fatiha Suresi - Abdulbasit Abdussamed", Youtube (9 Kasım 2019), 0:0:0-0:2:28

17 Reul McG, “al-Fatiha Tajwid Hussary, Mujawwad rendition”, Youtube (18 Aralık 2016), 0:0:0-0:1:34

18 https://ia800308.us.archive.org/17/items/minshavi/Infitar6-19-tarik1-17-fecr1-30-fatiha-bakara1-5285-286mescidiEmevi.mp3

19 Kur'an Medresesi مدرسة القرآن "Fatiha Suresi Şeyh Muhammed Rifat”, Youtube (27 Haziran 2017), 0:0:0-0:3:19 
Çiftçi, Misırlı Kârîlerin Mücevved Tilâvetlerinin Metro-Ritmik Karakteri

oranı nedir?

1.4.5. Mustafa İsmâil'in okuyuşunun ${ }^{20} \mathrm{CV}$ birim süre ortalaması ve uzun hece-kısa hece oranı nedir?

1.4.6. Şa ‘şâ̂̀'nin okuyuşunun ${ }^{21} \mathrm{CV}$ birim süre ortalaması ve uzun hece-kısa hece oranı nedir?

\subsection{Yöntem}

$\mathrm{Bu}$ araştırma betimsel bir karakterdedir. Örneklemi teşkil eden Fâtiha sûresinin okunuşlarındaki CV birim süre ortalaması ve uzun hece-kısa hece oranı, Praat fonetik analiz yazılım ${ }^{22}$ ile incelenerek belirlenmiştir. Elde edilen sayısal değerler tablo ve grafiklere işlenmiş, bu değerlerin karşılaştırmalı olarak ele alınmasıyla hipotezin test edilmesi sağlanmış ve bütüncül bir yargıya ulaşmaya çalışılmıştır.

\subsection{Sinırlamalar}

Elde edilen veriler ve bunlara bağlı olarak yapılan yorumlar, ulaşılabilen kaynaklar çerçevesindedir. Abdüssamed, Husarî, Minşâvî, Muhammed Rifat, Mustafa İsmâil ve Şa ‘şâ̂̀nin mücevved seyrindeki Fâtiha sûresî okuyuşları bu araştırmada analiz edilmiştir.

Euzu-besmele şeklinde kavramlaşarak Kur'an okuyuşlarının başında okunagelen iki cümle kalıbı incelemeden istisna edilmiştir. Zira bu kalıplaşma ve kavramlaşma, onun müzikal ve çoğu zaman metro-ritmik olarak tilâvetin genelinden ayrışmasına neden olmaktadır. Araştırmanın geçerli sonuçlara ulaşması düşüncesiyle bu istisna gerekli görülmüştür. ${ }^{23}$

Farklı verilerin ortaya çıkmasıyla daha farklı sonuçlara ulaşılması, her bilimsel araştırma için olduğu gibi bu araştırma için de imkan dahilindedir.

\subsection{Varsayımlar}

- Abdüssamed, Husarî, Minşâvî, Muhammed Rif'at, Mustafa İsmâil ve Şa ‘şâ̂i’nin Misır'in şöhretli okuyucularından olup Mısır tilâvet geleneğini temsil ettiği, Kur'an kıraat ve tilâveti konusunda alanı temsil kabiliyetine sahip olduğu, tilâvet için gerekli olan asgari müzik teori ve pratik bilgisine, yeterli teknik donanım ve doğaçlama kabiliyetine sahip olduğu,

- $\quad$ web ortamlarından elde edilen görüntüsüz ses kayıtlarının okuyucuların kendilerine ait

20 https://ia803102.us.archive.org/4/items/mustafa_mushaf_mucevved/1-Fatiha-Bakara1-28.mp3

https://www.caferilik.com/abd-ul-fettah-sasai-kadir-suresi-beyyine-suresi-zilzal-suresi-adiyat-suresi-kariasuresi-tekasur-suresi-asr-suresi-humeze-suresi-fil-suresi-kureys-suresi-maun-suresi-kevser-suresi-kafirun/

22 Praat: Doing Phonetics by Computer Version 6.1.32 (Yazılım, Hollanda: Paul Boersma - David Weenink, 1992).

$23 \mathrm{Bu}$ istisnanın, besmelenin Fâtiha sûresinin bir ayeti olup olmadığı tartışması ile bir ilgisi bulunmamaktadır. 
olduğu,

- araştırmada kullanılan Praat fonetik analiz yazılımının doğru ve güvenilir veriler sunduğu varsayılmaktadır.

\subsection{Evren ve Örneklem}

Araştırmamızın evren dairesini Mısır Kur'an tilâvet geleneği oluşturmaktadır. Örneklem kümesinde ise Abdüssamed, Husarî, Minşâvî, Muhammed Rif'at, Mustafa İsmâil ve Şa‘şâ̂̀nin mücevved seyrinde tilâvet ettikleri Fâtiha sûresi yer almaktadır.

\subsection{Veri Toplama ve İşleme Teknikleri}

$\mathrm{Bu}$ araştırmada örneklemi teşkil eden okuyucular 1882-1988 yılları arasında yaşamış olup, çağdaş olarak kategorize edilebilir. Okuyuş örneği tarama süreci, audio/video barındırma siteleri ve arama motoru olarak isimlendirilen web ortamlarında "mücevved, mujawwad, Fatiha (yabancı kaynaklara ulaşımı kolaylaştırmak ve genel yazım uygulamasına istinaden şapkalı a harfi kullanmadan)" gibi anahtar kelimeler ile okuyucu isimlerinin çeşitli kombinasyonları kullanılarak gerçekleştirilmiştir.

Araştırmamızda ele alacağımız Fâtiha sûresinin (bkz. Şekil 2) okunuşunun çözümlemesi için Praat yazılımı kullanılmıştır. Okuyuşlardaki medd-i tabî̀ (aslî med) haricindeki med, idgam ve ihfâ uygulamaları ile cümle aralarındaki susma süreleri dışarıda tutularak okuyuşun CV kalıbındaki birim hece süre ortalaması tespit edilmiştir. Diğer bir ifade ile bu hesaplamaya CV kalıbındaki kısa hece ile onun 2 katı değerde olduğu daha önceki araştırmalarımızda ${ }^{24}$ tespit edilen CVV (medd-i tabîi uygulaması) ve CVC kalıbındaki uzun hece dahil edilmiştir.

Şekil 1'e bakıldığında Praat yazılımının tilâvetler için ses dalgası, frekans, yoğunluk, formant ve pulsasyon düzeyinde sunduğu detaylı analiz imkanı yüzeysel olarak görülebilmektedir. Bunun yanında okuyuştaki, bir kelimenin unsuru olan hecelerin başlangıç ve bitiş noktalarının milisaniye düzeyinde işaretlenebildiği (örneğin; "el” hecesinin başladığı zaman noktası olan ve yukarıdan aşağı inen kesik kırmızı imleç çizginin bulunduğu 63 saniye 530 milisaniye), uzun ve kısa heceler arasındaki oransal ve zamansal boyutun belirgin bir şekilde ortaya konulabildiği görülmektedir.

24 Muhammed Recai Çiftçi, "Serbest Zamanlı Makamsal Okuyuşlar İçin Kullanılan 'Notasyonda Zamansal Tespit Yöntemi'nin Tutarlılığı (İhlâs Sûresi - Davut Kaya Örneği)”, Marmara Üniversitesi İlahiyat Fakültesi Dergisi 57 (2019), 6784; Muhammed Recai Çiftçi, “Kur'an'ın Makamsal Okunuşunun Zaman-Metin İlerlemesi (Topçuoğlu-Kaya Örneği)”, İslami Araştırmalar Dergisi 32/1 (2021), 84-98.

CVVC ile CVCC kalıbındaki heceler de uzun hece olmakla birlikte, bu araştırmalarda kapsam dışı bırakılmıştır. Zira bu kalıplardaki heceler, çeşitli harf kombinasyonları ile bulunduklarında "fer'î medler" olarak adlandırılan ve zamansal olarak çeşitlenen özel fonetik kurallara (tecvîd) tabi olmaktadır. 
Çiftçi, Mısırlı Kârîlerin Mücevved Tilâvetlerinin Metro-Ritmik Karakteri

Şekil 1: Praat Yazılımı “el-Hamdü” Kelime Analizi

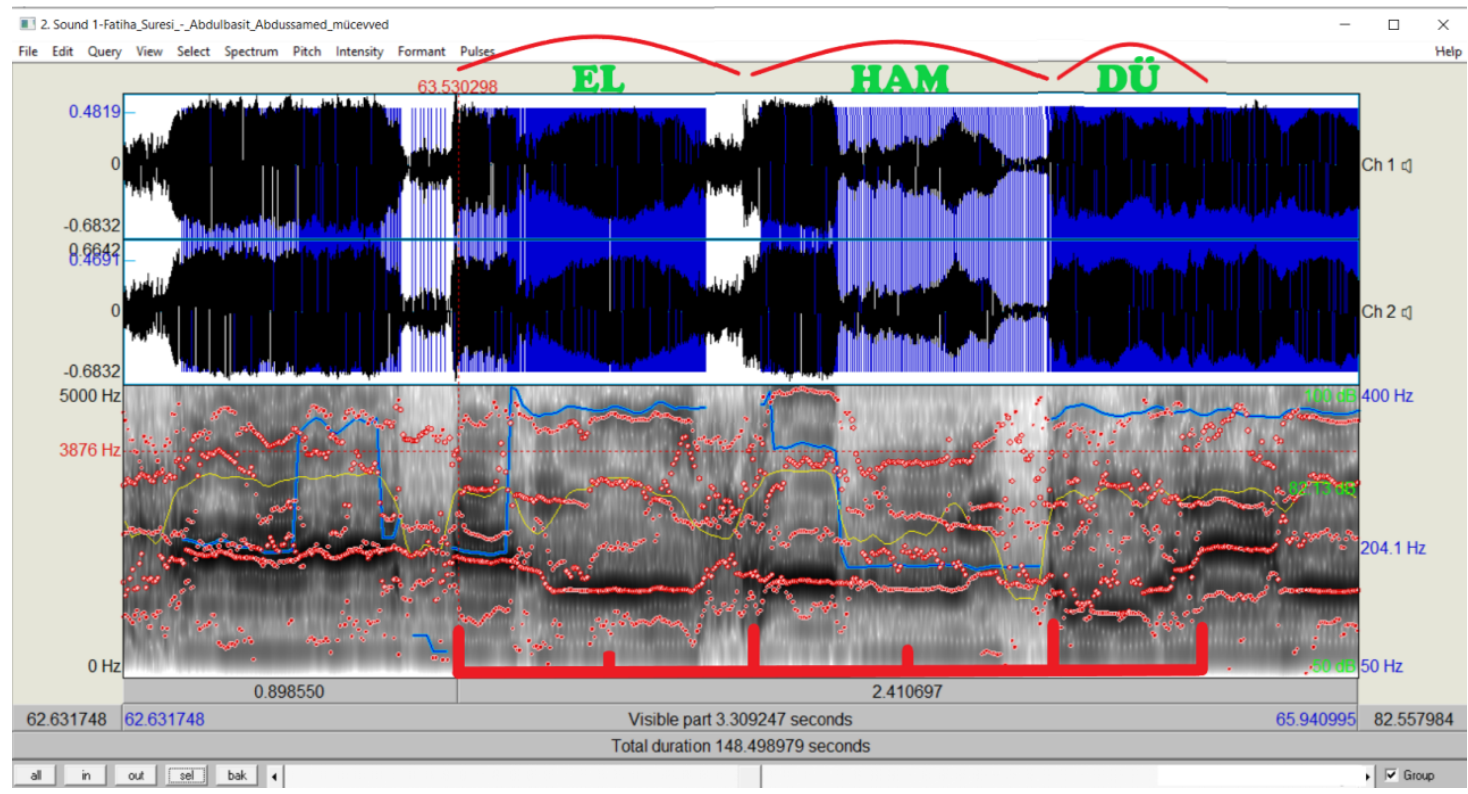

Araştırmalarımızda kullandığımız “ortalama değer” yaklaşımı araştırmalarımız için büyük önem taşımaktadır. Kendi içinde hız yönüyle tutarlı olmayan okuyuşlarda ortalama değer yaklaşımının, sonuçların geçerliliğinin sorgulanması yol açacağı öngörülebilir. Ancak alanında yetkin okuyucuların aynı seyir türündeki okuyuşlarında görülen hız dalgalanmalarının yüksek oranda belirgin olmadığı söylenebilir. Analitik bir yaklaşımla farkedilebilen dalgalanmaların ise mücevved okuyuş türü içinde tolerans düzeyinde olduğu ifade edilebilir. Bu sebeple okuyuştaki bir cümlenin ya da bütün okuyuşun hız değerinin tespitinde "ortalama değer" uygulamasının geçerli sonuçlar ortaya koyma gücü belirgin bir hale gelmektedir.

Şekil 2: Fâtiha Sûresinin Orijinal Metni ${ }^{25}$

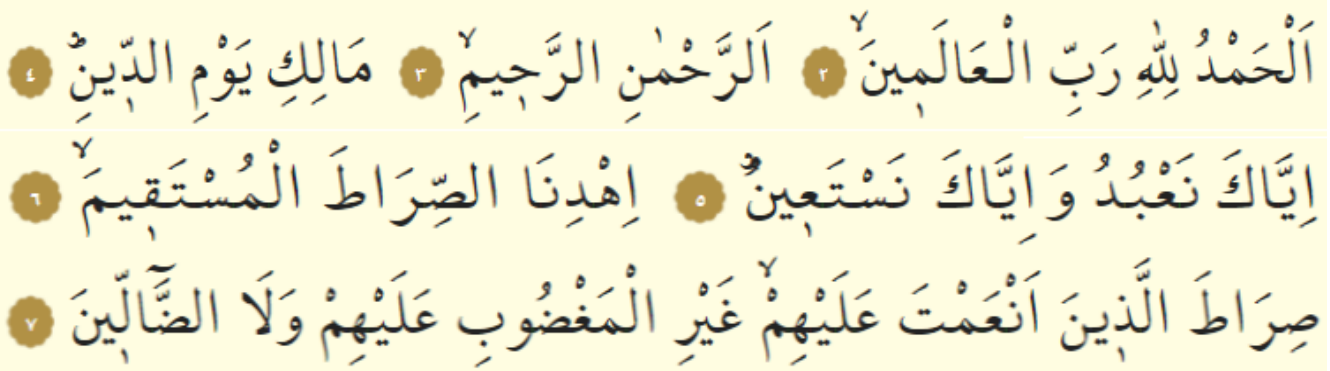

25 Diyanet İşleri Başkanlığı (DİB), “Kur'an-1 Kerim” (Erişim 7 Mayıs 2021). 
Fâtiha sûrenin basit transkripsiyonu ve bu araştırma çerçevesinde ayetleri karşılayan cümle numaraları şu şekildedir.

1. cümle: El-hamdü lillâhi Rabbi'l-âlemîn.

2. cümle: Er-Rahmâni'r-Rahîm.

3. cümle: Mâliki yevmi'd-dîn.

4. cümle : İyyâke na'büdü ve iyyâke neste'în.

5. cümle: İhdine's-sırâta'l-müstakîm.

6. cümle : Sirâta'l-lezîne en'amte aleyhim ğayri'l-mağdûbi aleyhim ve le'd-dâllîn.

Cümle numaralandırması, âyetlerin müstakil olarak numaralandırılmasına binaen yapılmış olup, kârîlerin tilâvetlerde bu cümle sistemine tam olarak riayet etmedikleri, cümleleri birbirine bağlayarak okuyabildikleri görülmektedir. Bu uygulama da âyetlerin hız düzeyinde birebir karşılaştırmasına engel olmaktadır. Araştırmamızda okuyucuların bu uygulaması göz ardı edilmiş, her âyet için müstakil olarak bir hız değeri ortaya konulmuş fakat bu değerler düzeyinde bir karşılaştırma yapılmamıştır. Okuyuşun genel hız tespiti için okuyucuların cümleleri tek tek veya birlikte okumalarının zaten bir etkisi bulunmamaktadır.

Ayetlerdeki zemini koyulaştırılmış son heceler, fer'î medleri içermesi sebebiyle analiz dışında bırakılan kısımlardır. CV kalıbındaki kısa heceler bold karakterle işaretlenmiştir. Bunların haricindekiler ise CVV ile CVC kalıbındaki 2 CV birimine karşlılk gelen hecelerdir. 3. cümledeki "Mâliki" kelimesinin bazı okuyuşlarda "Meliki” şeklinde okunduğu görülmektedir. Bu kelimedeki CVV kalıplı ilk hecenin CV kalıbındaki halinin okuyucu tarafından tercih edildiği durumlarda, hesaplamalar bu tercih baz alınarak yapılmıştır. Buna göre okuyuştaki 101 adet olarak tespit edilen toplam CV birim adedi, ilgili ayetin ve bütün okuyuşun CV birim süre ortalama hesaplamalarında 1 birim eksiltilmiştir.

Tablo 1: Okuyuşun Hız Değerinin Tespiti

\begin{tabular}{|c|c|c|c|c|c|c|}
\hline \multicolumn{4}{|c|}{ ABDÜSSAMED - MÜCEVVED } & \multicolumn{3}{|c|}{ 2. âyet (1. cümle) } \\
\hline Âyet & $\begin{array}{c}\text { CV bazlı } \\
\text { birim } \\
\text { adedi }\end{array}$ & Başlama & Bitiş & $\begin{array}{l}\text { Okuma } \\
\text { Süresi }\end{array}$ & $\begin{array}{c}\text { Birim } \\
\text { adedi } \\
\text { toplamı }\end{array}$ & $\begin{array}{c}\text { Birim } \\
\text { Ort. }\end{array}$ \\
\hline $\mathrm{El}$ & 2 & 63,53 & & 6,83 & 17 & 0,40 \\
\hline ham & 2 & & 65 & & & \\
\hline dü & 1 & 65 & 65,37 & & & \\
\hline lil & 2 & 65,37 & & & & \\
\hline lâ & 2 & & 67,14 & & & \\
\hline hi & 1 & 67,14 & 67,5 & & & \\
\hline $\mathrm{rab}$ & 2 & 67,5 & & & & \\
\hline bil & 2 & & & & & \\
\hline â & 2 & & 69,97 & & & \\
\hline le & 1 & 69,97 & 70,36 & & & \\
\hline mîn & & & & & & \\
\hline
\end{tabular}


Çiftçi, Mısırlı Kârîlerin Mücevved Tilâvetlerinin Metro-Ritmik Karakteri

Tablo 1'de bir okuyuşta bulunan hecelerin ortalama süresinin nasıl hesaplandığ1 görülmektedir. Ortaya çıan 0,40 saniye değeri bir hecenin ortalama okunma süresidir. Bu süre, söz konusu heceden bir dakika içinde kaç adet okunabileceğini gösteren CV-PM (CV per minute) değerine dönüştürülmekte ve okuyuşun hızı hesaplanabilmektedir. Bu süreç bütün okuyuş için işletilmektedir.

Tablo 2: Okuyuşlardaki Heceler Arası Oransal-Metrik İlişkinin Tespiti

\begin{tabular}{|c|c|c|c|c|c|c|c|c|c|c|c|}
\hline \multicolumn{4}{|c|}{ ABDÜSSAMED - MÜCEVVED } & \multicolumn{8}{|c|}{ Bu âyetteki (cümledeki) } \\
\hline Âyet & $\begin{array}{c}\text { CV bazlı } \\
\text { birim } \\
\text { adedi }\end{array}$ & Başlama & Bitiş & $\begin{array}{c}1 \text { adet CV } \\
\text { okuma } \\
\text { süresi }\end{array}$ & $\begin{array}{c}\mathrm{CV} \\
\text { toplam } \\
\text { süresi }\end{array}$ & $\begin{array}{c}\mathrm{CV} \\
\text { hece } \\
\text { adedi }\end{array}$ & $\begin{array}{l}\text { CV ort. } \\
\text { süresi }\end{array}$ & $\begin{array}{l}\mathrm{CVV} \text { ve } \mathrm{CVC} \\
\text { okuma süresi }\end{array}$ & $\begin{array}{l}\text { CVV ve } \\
\text { CVC } \\
\text { toplam } \\
\text { süresi }\end{array}$ & $\begin{array}{l}\text { CVV ve } \\
\text { CVC } \\
\text { hece } \\
\text { adedi }\end{array}$ & $\begin{array}{l}\text { CVV ve } \\
\text { CVC ort. } \\
\text { süresi }\end{array}$ \\
\hline $\mathrm{EI}$ & 2 & 63,53 & & & 1,12 & 3 & 0,37 & \multirow{2}{*}{1,47} & 5,71 & 7 & 0,82 \\
\hline ham & 2 & & 65 & & & & & & & & \\
\hline dü & 1 & 65 & & 0,37 & & & & & & & \\
\hline lil & 2 & 65,37 & & & & & & \multirow{2}{*}{1,77} & & & \\
\hline lâ & 2 & & 67,14 & & & & & & & & \\
\hline hi & 1 & 67,14 & & 0,36 & & & & & & & \\
\hline $\mathrm{rab}$ & 2 & 67,5 & & & & & & \multirow{3}{*}{2,47} & & & \\
\hline bil & 2 & & & & & & & & & & \\
\hline$\hat{\mathrm{a}}$ & 2 & & 69,97 & & & & & & & & \\
\hline le & 1 & 69,97 & 70,36 & 0,39 & & & & & & & \\
\hline mîn & & & & & & & & & & & \\
\hline
\end{tabular}

Bütün değerlerin saniye cinsinden işlendiği Tablo 2'de bir okuyuşta bulunan uzun ve kısa hecelerin sürelerinin ayrı ayrı hesaplanma süreci işlenmektedir. Bu okuyuştaki kısa hecelerin ortalamasının 0,37 saniye, uzun hecelerin ortalamasının ise 0,82 saniye olduğu anlaşılmaktadır. $\mathrm{Bu}$ iki değer birbirine oranlandığında ise $(0,82 / 0,37=2,2)$ bu okuyuştaki uzun ve kısa hecelerin birbiri ile olan metrik ilişkisi ortaya çıkmaktadır. Bu süreç de bütün okuyuş için işletilmektedir.

Bu tablodaki birim adedi ile hece adedi ifadeleri birbirine karıştırılmamalıdır. Hece adedi "rab" hecesi örneği için 1 iken, birim adedi CV bazlı olduğundan bu hece için 2'dir. Bir diğer ifadeyle "CV bazlı" derken bir hecenin kaç adet kısa heceye karşıllı geldiği kastedilmektedir.

Araştırmamızın bütününde kullanılan kavramlardan hız-tempo-seyir-biçim-stil ile, tilâvetokuyuş ile, kârî-okuyucu-hafız ile, yavaşlama-ağırlaşma ile aynı anlam dairesinde kullanılabilmektedir.

\section{Bulgular ve Yorumlar}

\subsection{Zamansal Özellikler}

\subsubsection{Abdüssamed}


Çiftçi, The Metro-Rhythmic Character of Mujawwad Recitations of the Egyptian Reciters

Tablo 3: Abdüssamed Mücevved Fâtiha Okuyuşu Zamansal Özellikleri

\begin{tabular}{|c|c|c|c|}
\hline $\begin{array}{c}\text { ABDÜSSAMED } \\
\text { MÜCEVVED } \\
\text { FÂTiHÂA }\end{array}$ & $\begin{array}{c}\text { CV } \\
\text { Birim } \\
\text { Adedi }\end{array}$ & $\begin{array}{c}\text { Okuma } \\
\text { Süresi } \\
\text { (sn.) }\end{array}$ & $\begin{array}{c}\text { CV Birimi } \\
\text { Süre Ort. } \\
\text { (sn.) }\end{array}$ \\
\hline 1. cümle & 17 & 6,83 & 0,40 \\
\hline 2. cümle & 9 & 3,65 & 0,41 \\
\hline 3. cümle & 7 & 2,9 & 0,41 \\
\hline 4. cümle & 18 & 6,48 & 0,36 \\
\hline 5. cümle & 13 & 4,15 & 0,32 \\
\hline 6. cümle & 36 & 14,66 & 0,41 \\
\hline Tamamı & $\mathbf{1 0 0}$ & $\mathbf{3 8 , 6 7}$ & $\mathbf{0 , 3 9}$ \\
\hline
\end{tabular}

Mücevved seyrinin kullanıldığı bu okuyuşta -her ne kadar tabloda yuvarlamadan kaynaklanan benzerlik görülse de milisaniye düzeyinde- ikinci ve üçüncü cümleye geçişin nisbeten ağırlaşarak gerçekleştiği görülmektedir. Son cümleye kadar kademe kademe hız kazanan okuyuşun altıncı cümlesinde kayda değer bir ağırlaşma yaşandığı söylenebilir.

\subsubsection{Husarî}

Tablo 4: Husarî Mücevved Fâtiha Okuyuşu Zamansal Özellikleri

\begin{tabular}{|c|c|c|c|}
\hline $\begin{array}{c}\text { HUSARî } \\
\text { MÜCEVVED } \\
\text { FÂTiHÂ }\end{array}$ & $\begin{array}{c}\text { CV } \\
\text { Birim } \\
\text { Adedi }\end{array}$ & $\begin{array}{c}\text { Okuma } \\
\text { Süresi } \\
\text { (sn.) }\end{array}$ & $\begin{array}{c}\text { CV Birimi } \\
\text { Süre Ort. } \\
\text { (sn.) }\end{array}$ \\
\hline 1. cümle & 17 & 5,19 & 0,31 \\
\hline 2. cümle & 9 & 3,4 & 0,38 \\
\hline 3. cümle & 8 & 3,14 & 0,39 \\
\hline 4. cümle & 18 & 6,74 & 0,37 \\
\hline 5. cümle & 13 & 4,49 & 0,35 \\
\hline 6. cümle & 36 & 13,55 & 0,38 \\
\hline Tamamı & $\mathbf{1 0 1}$ & $\mathbf{3 6 , 5 1}$ & $\mathbf{0 , 3 6}$ \\
\hline
\end{tabular}

Mücevved okuyuşunda ikinci ve üçüncü cümleye geçişini ağırlaşarak gerçekleştiren Husarî, dördüncü ve beşinci cümlelere geçerken kademe kademe hızlanmaktadır. Son cümlede ise görece bir ağırlaşma görülmektedir.

\subsubsection{Minşâvî}

Tablo 5: Minşâvî Mücevved Fâtiha Okuyuşu Zamansal Özellikleri

\begin{tabular}{|c|c|c|c|}
\hline $\begin{array}{c}\text { MiNŞAVî } \\
\text { MÜCEVVED } \\
\text { FÂTiHÂA }\end{array}$ & $\begin{array}{c}\text { CV } \\
\text { Birim } \\
\text { Adedi }\end{array}$ & $\begin{array}{c}\text { Okuma } \\
\text { Süresi } \\
\text { (sn.) }\end{array}$ & $\begin{array}{c}\text { CV Birimi } \\
\text { Süre Ort. } \\
\text { (sn.) }\end{array}$ \\
\hline 1. cümle & 17 & 6,78 & 0,40 \\
\hline 2. cümle & 9 & 3,7 & 0,41 \\
\hline 3. cümle & 7 & 3,04 & 0,43 \\
\hline 4. cümle & 18 & 6,39 & 0,35 \\
\hline 5. cümle & 13 & 3,32 & 0,26 \\
\hline 6. cümle & 36 & 13,95 & 0,39 \\
\hline Tamamı & $\mathbf{1 0 0}$ & $\mathbf{3 7 , 1 8}$ & $\mathbf{0 , 3 7}$ \\
\hline
\end{tabular}


Mücevved seyrindeki okuyuşunda Minşâvînin ikinci ve üçüncü cümlelere geçerken görece ağırlaştığı anlaşılmaktadır. Dördüncü cümle geçişinde bariz bir hızlanma görülen okuyuşta beşinci cümle geçişinin de belirgin bir hız kazandığı söylenebilir. Son cümleye geçişte ise okuyuşun görece sert bir ağırlaşma kaydettiği anlaşılmaktadır.

\subsubsection{Muhammed Rifat}

Tablo 6: Muhammed Rif at Mücevved Fâtiha Okuyuşu Zamansal Özellikleri

\begin{tabular}{|c|c|c|c|}
\hline $\begin{array}{c}\text { M. RiF'AT } \\
\text { MÜCEVVED } \\
\text { FÂTiHÂA }\end{array}$ & $\begin{array}{c}\text { CV } \\
\text { Birim } \\
\text { Adedi }\end{array}$ & $\begin{array}{c}\text { Okuma } \\
\text { Süresi } \\
\text { (sn.) }\end{array}$ & $\begin{array}{c}\text { CV Birimi } \\
\text { Süre Ort. } \\
\text { (sn.) }\end{array}$ \\
\hline 1. cümle & 17 & 6,44 & 0,38 \\
\hline 2. cümle & 9 & 3,54 & 0,39 \\
\hline 3. cümle & 7 & 3,04 & 0,43 \\
\hline 4. cümle & 18 & 8,25 & 0,46 \\
\hline 5. cümle & 13 & 5,5 & 0,42 \\
\hline 6. cümle & 36 & 16,56 & 0,46 \\
\hline Tamamı & $\mathbf{1 0 0}$ & $\mathbf{4 3 , 3 3}$ & $\mathbf{0 , 4 3}$ \\
\hline
\end{tabular}

Muhammed Rifat dördüncü cümleye kadar diğer okuyucularla aynı ağırlaşma refleksini göstermekte iken, dördüncü cümlede ağırlaşmaya devam etmiştir. Beşinci cümleye geçişte hız kazanan okuyuş, son cümlede tekrar aynı tempoya dönmüştür.

\subsubsection{Mustafa İsmâil}

Tablo 7: Mustafa İsmâil Mücevved Fâtiha Okuyuşu Zamansal Özellikleri

\begin{tabular}{|c|c|c|c|}
\hline $\begin{array}{c}\text { M. isMÂiL } \\
\text { MÜCEVVED } \\
\text { FÂTiHÂ }\end{array}$ & $\begin{array}{c}\text { CV } \\
\text { Birim } \\
\text { Adedi }\end{array}$ & $\begin{array}{c}\text { Okuma } \\
\text { Süresi } \\
\text { (sn.) }\end{array}$ & $\begin{array}{c}\text { CV Birimi } \\
\text { Süre Ort. } \\
\text { (sn.) }\end{array}$ \\
\hline 1. cümle & 17 & 3,59 & 0,21 \\
\hline 2. cümle & 9 & 2,95 & 0,33 \\
\hline 3. cümle & 8 & 3,27 & 0,41 \\
\hline 4. cümle & 18 & 6,18 & 0,34 \\
\hline 5. cümle & 13 & 4,28 & 0,33 \\
\hline 6. cümle & 36 & 12,62 & 0,35 \\
\hline Tamamı & $\mathbf{1 0 1}$ & $\mathbf{3 2 , 8 9}$ & $\mathbf{0 , 3 3}$ \\
\hline
\end{tabular}

Okuyucunun mücevved seyrini kullandığı okuyuşundaki cümlelerin CV birim süre ortalamalarını içeren tablo analiz edildiğinde, ilk cümlenin okuyuşun geneline oranla çok hızlı okunduğu görülmektedir. İkinci ve üçüncü cümleye geçerken belirgin biçimde ağırlaşan okuyuşun dördüncü ve beşinci cümlelerde hız kazandığı, son cümlede ise hafifçe ağırlaştı̆̆ı söylenebilir. 
Çiftçi, The Metro-Rhythmic Character of Mujawwad Recitations of the Egyptian Reciters

\subsection{6. Şa'şâ̂i}

Tablo 8: Şa'şâî Mücevved Fâtiha Okuyuşu Zamansal Özellikleri

\begin{tabular}{|c|c|c|c|}
\hline $\begin{array}{c}\text { ŞA'ŞÂẦ } \\
\text { MÜCEVVED } \\
\text { FÂTiHÂA }\end{array}$ & $\begin{array}{c}\text { CV } \\
\text { Birim } \\
\text { Adedi }\end{array}$ & $\begin{array}{c}\text { Okuma } \\
\text { Süresi } \\
\text { (sn.) }\end{array}$ & $\begin{array}{c}\text { CV Birimi } \\
\text { Süre Ort. } \\
\text { (sn.) }\end{array}$ \\
\hline 1. cümle & 17 & 6,27 & 0,37 \\
\hline 2. cümle & 9 & 3,13 & 0,35 \\
\hline 3. cümle & 8 & 3,25 & 0,41 \\
\hline 4. cümle & 18 & 6,92 & 0,38 \\
\hline 5. cümle & 13 & 4,84 & 0,37 \\
\hline 6. cümle & 36 & 14,39 & 0,40 \\
\hline Tamamı & $\mathbf{1 0 1}$ & $\mathbf{3 8 , 8}$ & $\mathbf{0 , 3 8}$ \\
\hline
\end{tabular}

Okuyucunun ikinci cümleye geçerken diğer okuyuculardaki refleksin aksine nisbeten hız kazandığı görülmektedir. Üçüncü cümleye geçişte ağırlaşan okuyuş, altıncı cümleye kadar görece hız kazanmış, son cümlede ise ağırlaşma kaydetmiştir.

\subsection{Metrik Özellikler}

\subsubsection{Abdüssamed}

Tablo 9: Abdüssamed Mücevved Fâtiha Okuyuşu Metrik Özellikleri

\begin{tabular}{|c|c|}
\hline $\begin{array}{c}\text { ABDÜSSAMED } \\
\text { MÜCEVVED } \\
\text { FÂTiHÂA }\end{array}$ & $\begin{array}{c}\text { Uzun/Kısa } \\
\text { hece oranı }\end{array}$ \\
\hline 1. cümle & 2,20 \\
\hline 2. cümle & 2,15 \\
\hline 3. cümle & 2,28 \\
\hline 4. cümle & 1,92 \\
\hline 5. cümle & 1,94 \\
\hline 6. cümle & 2,15 \\
\hline Tamamı & $\mathbf{2 , 1}$ \\
\hline
\end{tabular}

Abdüssamed'in mücevved okuyuşunda uzun hecelerin süre ortalamasının kısa hecelerin süre ortalamasına oranının çok yakın bir değerle 2 tam sayısını gösterdiği anlaşılmaktadır.

\subsubsection{Husarî}

Tablo 10: Husarî Mücevved Fâtiha Okuyuşu Metrik Özellikleri

\begin{tabular}{|c|c|}
\hline $\begin{array}{c}\text { HUSARî } \\
\text { MÜCEVVED } \\
\text { FÂTiHÂ }\end{array}$ & $\begin{array}{c}\text { Uzun/Kısa } \\
\text { hece oranı }\end{array}$ \\
\hline 1. cümle & 2,16 \\
\hline 2. cümle & 2,18 \\
\hline 3. cümle & 2,24 \\
\hline 4. cümle & 2,15 \\
\hline 5. cümle & 2,18 \\
\hline 6. cümle & 1,99 \\
\hline Tamamı & $\mathbf{2 , 1}$ \\
\hline
\end{tabular}


Okuyucunun mücevved seyrini kullandığı okuyuşundaki uzun hecelerin süre ortalamasının kısa hecelerin süre ortalamasına oranı çok yakın bir değerle 2 tam sayısını göstermektedir.

\subsubsection{Minşâvî}

Tablo 11: Minşâvî Mücevved Fâtiha Okuyuşu Metrik Özellikleri

\begin{tabular}{|c|c|}
\hline $\begin{array}{c}\text { MiNŞÂVî } \\
\text { MÜCEVVED } \\
\text { FÂTiHÂA }\end{array}$ & $\begin{array}{c}\text { Uzun/Kısa } \\
\text { hece oranı }\end{array}$ \\
\hline 1. cümle & 2,17 \\
\hline 2. cümle & 2,18 \\
\hline 3. cümle & 2,06 \\
\hline 4. cümle & 1,89 \\
\hline 5. cümle & 1,86 \\
\hline 6. cümle & 2,10 \\
\hline Tamamı & $\mathbf{2 , 0}$ \\
\hline
\end{tabular}

Minşâvînin mücevved okuyuşunda uzun hecelerin süre ortalamasının kısa hecelerin süre ortalamasına oranının 2 tam sayısını işaret ettiği görülmektedir.

\subsubsection{Muhammed Rifat}

Tablo 12: Muhammed Rif'at Mücevved Fâtiha Okuyuşu Metrik Özellikleri

\begin{tabular}{|c|c|}
\hline $\begin{array}{c}\text { M. RiF'AT } \\
\text { MÜCEVVED } \\
\text { FÂTiHÂ }\end{array}$ & $\begin{array}{c}\text { Uzun/Kısa } \\
\text { hece oranı }\end{array}$ \\
\hline 1. cümle & 2,28 \\
\hline 2. cümle & 2,28 \\
\hline 3. cümle & 2,27 \\
\hline 4. cümle & 2,34 \\
\hline 5. cümle & 2,51 \\
\hline 6. cümle & 1,91 \\
\hline Tamamı & $\mathbf{2 , 1}$ \\
\hline
\end{tabular}

Okuyucunun mücevved seyrini kullandığı okuyuşundaki uzun hecelerin süre ortalamasının kısa hecelerin süre ortalamasına oranı çok yakın bir değerle 2 tam sayısını göstermektedir.

\subsubsection{Mustafa İsmâil}

Tablo 13: Mustafa İsmâil Mücevved Fâtiha Okuyuşu Metrik Özellikleri

\begin{tabular}{|c|c|}
\hline $\begin{array}{c}\text { M. isMÂiL } \\
\text { MÜCEVVED } \\
\text { FÂTiHÂ }\end{array}$ & $\begin{array}{c}\text { Uzun/Kısa } \\
\text { hece oranı }\end{array}$ \\
\hline 1. cümle & 1,90 \\
\hline 2. cümle & 1,86 \\
\hline 3. cümle & 2,24 \\
\hline 4. cümle & 1,97 \\
\hline 5. cümle & 2,29 \\
\hline 6. cümle & 2,16 \\
\hline Tamamı & $\mathbf{2 , 0}$ \\
\hline
\end{tabular}


Mustafa İsmâil'in mücevved okuyuşunda uzun hecelerin süre ortalamasının kısa hecelerin süre ortalamasına oranının 2 tam sayısını işaret ettiği görülmektedir.

\subsection{6. Şa'şâî}

Tablo 14: Şa'şâ̂i Mücevved Fâtiha Okuyuşu Metrik Özellikleri

\begin{tabular}{|c|c|}
\hline $\begin{array}{c}\text { ŞA'ŞÂÎ } \\
\text { MüCEVVED } \\
\text { FÂTiHÂA }\end{array}$ & $\begin{array}{c}\text { Uzun/Kısa } \\
\text { hece oranı }\end{array}$ \\
\hline 1. cümle & 2,04 \\
\hline 2. cümle & 2,20 \\
\hline 3. cümle & 2,04 \\
\hline 4. cümle & 1,98 \\
\hline 5. cümle & 2,19 \\
\hline 6. cümle & 2,28 \\
\hline Tamamı & $\mathbf{2 , 1}$ \\
\hline
\end{tabular}

Okuyucunun mücevved seyrini kullandığı okuyuşundaki uzun hecelerin süre ortalamasının kısa hecelerin süre ortalamasına oranı çok yakın bir değerle 2 tam sayısını göstermektedir.

\section{Karşılaştırma ve Değerlendirmeler}

\subsection{Zamansal Özellikler}

Tablo 15: Mısırlı Hafızların Okuyuşlarının Karşılaştırmalı Zamansal Özellikleri

\begin{tabular}{|c|c|c|c|c|c|c|}
\hline & Abdüssamed & Husarî & Minşâvî & M. Rif'at & M. İsmâil & Şa'şâî \\
\hline $\begin{array}{c}\text { Bütün } \\
\text { okuyusunu } \\
\text { CV süre ort. } \\
\text { (sn.) }\end{array}$ & 0,39 & 0,36 & 0,37 & 0,43 & 0,33 & 0,38 \\
\hline
\end{tabular}

Mısırlı kârîlerin okuyuşlarının CV süre ortalamalarını içeren bu tablo incelendiğinde okuyuşların CV birim süre ortalamasının 0,33 - 0,43 saniye aralığında olduğu görülmektedir. $\mathrm{Bu}$ aralıkta Abdüssamed, Husarî, Minşâvî ve Şa şâ̂înnin okuyuşlarının bu iki değerin orta bölgesinde yoğunlaştı̆̆ı, buna karşın Muhammed Rif'at ve Mustafa İsmâil'in okuyuşlarının ise iki uç sınırı teşkil ettiği söylenebilir.

Tablo 16: Mısırlı kârîlerin okuyuşlarının CV-PM değerleri

\begin{tabular}{|c|c|c|c|}
\hline $\begin{array}{c}\text { MÜCEVVED } \\
\text { OKUYUŞ TEMPO } \\
\text { DEĞERLERI }\end{array}$ & $\begin{array}{c}\text { Toplam } \\
\text { okuyuş } \\
\text { süresi (sn.) }\end{array}$ & $\begin{array}{c}\text { Uzunluk } \\
\text { birimi genel } \\
\text { ort. (sn.) }\end{array}$ & $\begin{array}{c}\text { CV-PM } \\
\text { değeri }\end{array}$ \\
\hline Abdüssamed & 38,62 & 0,39 & $\mathbf{1 5 5}$ \\
\hline Husarî & 36,35 & 0,36 & $\mathbf{1 6 7}$ \\
\hline Minşâvî & 36,75 & 0,37 & 163 \\
\hline M. Rif'at & 43,29 & 0,43 & 138 \\
\hline M. İsmâil & 32,83 & 0,33 & 185 \\
\hline Şa'şâî & 38,76 & 0,38 & $\mathbf{1 5 6}$ \\
\hline
\end{tabular}


Çiftçi, Misırlı Kârîlerin Mücevved Tilâvetlerinin Metro-Ritmik Karakteri

CV-PM değerlerini içeren bu tabloya göre okuyuşlar 138 ile 185 CV-PM arasındaki bir hız skalasında dağılım göstermiştir. En uzun süreli okuyuş ile en kısa süreli okuyuş arasında da 10 saniyelik bir fark olduğu anlaşılmaktadır. Okuyuşlar arasında zamansal yönden genel olarak benzeşmenin olduğu söylenebilir.

\subsection{Metrik Özellikler}

Tablo 17: Mısırlı kârîlerin mücevved okuyuşlarının metrik özellikleri

\begin{tabular}{|c|c|c|c|c|c|c|}
\hline METRik & Abdüssamed & Husarî & Minşâvî & M. Rif'at & M. İsmâil & Şa'şâî \\
\hline $\begin{array}{c}\text { Okuyuştaki } \\
\text { Uzun-Kısa }\end{array}$ & 2,1 & 2,1 & 2,0 & 2,1 & 2,0 & 2,1 \\
$\begin{array}{c}\text { Hece Oranı } \\
\text { Ort. }\end{array}$ & 2,1 & & & \\
\hline
\end{tabular}

Mücevved okuyuşlardaki uzun hecelerin kısa hecelere oranının yaklaşık olarak 2 tam sayısını çok yüksek oranda işaret ettiği bu tablodan anlaşılmaktadır.

\section{Sonuç}

Okuyuşların zamansal/tempo özellikleri çerçevesinde ulaşılabilecek olan sonuç, okuyuşların genel olarak benzeştikleri yönündedir. Metrik özelliklere bakıldığında ise zamansal özelliklere göre daha belirgin ve yüksek oranlı bir benzeşmeden bahsedilebilmektedir. Bu sonuçlar bizi, okuyuşların dayandığı metindeki metrik yönün zamansal karaktere göre daha muhkem ve daha az esnek bir özellik arzettiği sonucuna ulaştırmaktadır. Bir diğer ifadeyle bir okuyuşun metrik özellikleri, okuyuşun hız karakterine göre şekillenmemekte, bilakis hız unsurunun üzerine inşa edildiği bağımsız bir dinamik olarak belirginlik kazanmaktadır.

$\mathrm{Bu}$ araştırmanın "Mısırlı kârîlerin mücevved seyrindeki okuyuşları karşılaştırmalı olarak analiz edildiğinde zamansal ve metrik özelliklerinin benzeștiği görülür" şeklinde tesis edilen araştırma hipotezinin büyük oranda doğrulanabilir olduğu görülmektedir.

$\mathrm{Bu}$ araştırmamız ile Kur'an'ın zamansal ve metro-ritmik özelliklerinin analiz edildiği diğer çalışmalarımızda da ifade edildiği üzere, okuyuşların seyir özelliklerinde görülen hızlanma ve ağırlaşmalar, teknik analizlerle ortaya çıkabilen değerlere istinaden anlaşılabilmektedir. Bunun temel sebebi, örneklem olarak aynı hız kategorisinde olan okuyuşların seçilmesidir. İncelediğimiz okuyuşların hızında da çok belirgin dalgalanmaların olmadığı görülebilir. Sadece; en hızlı ve en yavaş okuyuşun beraber dinlenmesi ile ayırt edilebilecek küçük düzeyli bir farklılaşmanın olduğu söylenebilir. 10 saniyelik bir farkın oluştuğu bu iki okuyuş, mücevved okuyuş olma açısından değerlendirilecek olursa her iki okuyuşun da ilk planda mücevved okuyuş tariflerine girebileceği görülmektedir. Her iki okuyuşun da murattel okuyuş olarak bilinen okuyuş biçimine göre daha ağır 
karakterde oldukları söylenebilir. Cümleleri arasında uzun duraklamalar ile görece ağdalı müzikal ifadeler ve melizmatik melodiler görülmektedir. Şu durumda, aynı hız kategorisinde değerlendirilen okuyuşlar için algılabilir bir hız değişimi bulunmasının bu okuyuşların farklı bir kategoride değerlendirilmesini gerektirecek düzeye ulaşmamış olduğu ifade edilebilir.

\section{Öneriler}

Her ne kadar araştırmamızda âyetler arasında zamansal karşılaştırma yapılmamış olsa da, tablolara yansıyan cümle hız değerlerindeki dalgalanmaların sebepleri de ayrı bir araştırma konusu olarak karşımıza çıkma gücünü taşımaktadır. Zira metrik düzeyde çok yüksek düzeyli bir benzeşme söz konusu iken hız çerçevesinde yaşanan küçük ölçekli ayrışmalara sebep olan dinamiklerin ne olduğu ile müziksellik veya fonetik gibi etkenlerin okuyuşun zamansallığına etkisi tartışmaya değer konular olmaya adaydır.

Mısır'daki tilâvet geleneklerinde kullanılan diğer seyir biçimi olan murattel okuyuşun mücevved okuyuş biçimi ile karşılaştırması, kıraat, müzik, dilbilim gibi disiplinlere gönül veren akademisyenler için ele alınması gereken ayrı bir konu olarak karşımızda durmaktadır.

Kimi bilim insanlarınca Kur'an tilâveti konusunda mevcut estetik merkezin 21. yüzyılda Körfez ülkelerine kaymakta olduğ $u^{26}$ ifade edilmektedir. Bu ülkelerdeki kârîlerin okuyuşlarının, Kur'an tilâvetinin inceleme alanına girdiği disiplinler için bir araştırma konusu olma ihtimali de günümüz için göz ardı edilmemelidir.

\section{Kaynakça}

Praat: Doing Phonetics by Computer Version 6.1.32. Yazılım. Hollanda: Paul Boersma - David Weenink, 1992. http://www.praat.org/

Buhârî, Ebû Abdillâh Muhammed b. İsmail. el-Câmi'u's-sahîh. nşr. Mustafa Dib el-Buga. 6 Cilt. b.y.: Daru İbn Kesir, 1407/1987.

Çağıl, Necdet. Kur'an Belagati ve Fonetiği Yönünden Kiraatler. Erzurum: Atatürk Üniversitesi, Sosyal Bilimler Enstitüsü, Doktora Tezi, 2002.

Çiftçi, Muhammed Recai. "Serbest Zamanlı Makamsal Okuyuşlar İçin Kullanılan 'Notasyonda Zamansal Tespit Yöntemi'nin Tutarlılığı (İhlâs Sûresi - Davut Kaya Örneği)”. Marmara $\begin{array}{lllll}\text { Üniversitesi İlahiyat } & \text { Fakültesi Dergisi } & 57 & \text { (2019), }\end{array}$

26 Lauren Evans Osborne, From text to sound to perception: Modes and relationships of meaning in the recited Qur'an (Chicago: The University of Chicago, 2014), 154. 
Çiftçi, Mısırlı Kârîlerin Mücevved Tilâvetlerinin Metro-Ritmik Karakteri

https://doi.org/10.15370/maruifd.679214

Çiftçi, Muhammed Recai. “Kur'an'ın Makamsal Okunuşunun Zaman-Metin İlerlemesi (TopçuoğluKaya Örneği)”. İslami Araştırmalar Dergisi 32/1 (2021), 84-98.

Dağdeviren, Alican. “Kur'an'ın Fonetik İ'cazı”. Sakarya Üniversitesi İlahiyat Fakültesi Dergisi 20/2 (2009), 69-88.

DİB, Diyanet İşleri Başkanlığı. "Kur'an-1 Kerim”. Erişim 7 Mayıs 2021. https://kuran.diyanet.gov.tr/mushaf/kuran-1/fatiha-suresi-1/ayet-1/diyanet-isleribaskanligi-meali-1

al-Faruqi, Lois Ibsen. "The Cantillation of the Qur'an". Asian Music 19/1 (1987), 2-25. https://doi.org/10.2307/833761

Frishkopf, Michael. "Mediated Qur'anic Recitation and the Contestation of Islam in Contemporary Egypt". Music and the Play of Power in the Middle East, North Africa and Central Asia. ed. Laudan Nooshin. 75-114. Farnham, Surrey: Ashgate, 2009.

Graham, William A. - Kermani, Navid. "Recitation and Aesthetic Reception". The Cambridge Companion to the Qur'ān. ed. Jane Dammen McAuliffe. 115-142. Cambridge: Cambridge University Press, 2006.

el-Husari, Muhammed Mahmud Halil. "Mahmûd Halîl Husarî". Türkiye Diyanet Vakfi İslâm Ansiklopedisi. 18/412-413. Ankara: TDV Yayınları, 1998.

Koç, Turan. İslam Estetiği. İstanbul: İsam Yayınları, 2009.

Murâd, Saîd. "Muhammed Rif'at". Türkiye Diyanet Vakfi İslâm Ansiklopedisi. 30/566-567. Ankara: TDV Yayınları, 2005.

Murâd, Saîd. "Muhammed Sıddîk Minşâvî”. Türkiye Diyanet Vakfi İslâm Ansiklopedisi. 30/117. Ankara: TDV Yayınları, 2005.

Murâd, Saîd. "Mustafa İsmâil”. Türkiye Diyanet Vakfi İslâm Ansiklopedisi. 31/303-304. Ankara: TDV Yayınları, 2006.

Murâd, Saîd. "Şa'şâ̂̂”. Türkiye Diyanet Vakfi İslâm Ansiklopedisi. 38/367. Ankara: TDV Yayınları, 2010.

Huzur veren Sesler. "Fatiha Suresi - Abdulbasit Abdussamed". Youtube. 9 Kasim 2019. https://www.youtube.com/watch?v=IxotoRHQesM

Nelson, Kristina. "Reciter and Listener: Some Factors Shaping the Mujawwad Style of Qur'anic 
Çiftçi, The Metro-Rhythmic Character of Mujawwad Recitations of the Egyptian Reciters

Reciting". Ethnomusicology 26/1 (1982), 41-47.

Nelson, Kristina. The Art of Reciting the Qur'an. Cairo: American University in Cairo Press, 2001.

Okçu, Abdülmecit. “Kur’an Tilavetinde Ezgi”. Dinî Araştırmalar 10/28 (2007), 213-247.

Osborne, Lauren Evans. “Textual and Paratextual Meaning in the Recited Qur'an: Analysis of a Performance of Surat al-Furqan by Sheikh Mishary bin Rashid al-Afasy". Qur'anic Studies Today. ed. Angelika Neuwirth and Michael Sells. 228-246. New York: Routledge, 2016.

Osborne, Lauren Evans. From text to sound to perception: Modes and relationships of meaning in the recited Qur'an. Chicago: The University of Chicago, 2014.

Özel, Ahmet. “Abdülbâsıt Muhammed Abdüssamed”. Türkiye Diyanet Vakfi İslâm Ansiklopedisi. 1/300. Ankara: TDV Yayınları, 1988.

Pacholczyk, Józef M. Regulative principles in the Koran chant of Shaikh 'Abdu'l-Basit 'Abdu's Samad. Los Angeles: University of California, 1970.

Racy, Ali Jihad. Arap Dünyasında Müzik: Tarab Kültürü ve Sanatı. İstanbul: Ayrıntı, 2007.

Reul McG, "al-Fatiha Tajwid Hussary, Mujawwad rendition”. Youtube. 18 Aralı 2016. https://www.youtube.com/watch?v=deegmI8-egQ

Sells, Michael Anthony. Approaching the Qur'an: The Early Revelations. Ashland, Or: White Cloud Press, 2007.

Kur'an Medresesi مدرسة القرآن, “Fatiha Suresi Şeyh Muhammed Rifat”. Youtube. 27 Haziran 2017. https://www.youtube.com/watch?v=eF4sup_OfwU

Yılmaz, Muhammet. "Muhammed Ebû Zehre’ye Göre Kur'an'ın Teğannî ile Okunuşu”. Recep Tayyip Erdoğan Üniversitesi İlahiyat Fakültesi Dergisi 18 (2020), 93-111. 
Çiftçi, Mıstrlı Kârîlerin Mücevved Tilâvetlerinin Metro-Ritmik Karakteri

\section{The Metro-Rhythmic Character of Mujawwad Recitations of the Egyptian Reciters}

\section{Extended Summary}

In today's Islamic world, when it comes to recitation of the Qur'an, countries such as Egypt in North Africa, such as Iraq, Saudi Arabia and Kuwait in the Gulf region, and countries such as Indonesia and Malaysia in the Far East are more prominent. Among these, it is seen that Cairo is in a dominant position compared to other centers such as Istanbul, Damascus, Baghdad, Mecca and Medina.

A very active recitation culture and tradition is kept alive in Egypt. It can be seen that many listeners record reciters' recitations with various recording devices in their hands. In the reciting process, there is an effective communication and interaction between the reciters and the audience, and the obvious gestures of them can be easily observed. The audience also calls for repeats, shouting up suggestions to the reciter and special requests for maqamat. There may also be some musical references to other reciters, and the knowledgeable audience will shout out its delighted recognition with the name of the reciter quoted.

Qur'an recitation in Egypt broadly consists of two forms, mujawwad and morattal. Morattal is a simple chant using a set pattern of limited musical range and phraseology. However, mujawwad refers to a slow recitation that deploys heightened technical artistry and melodic modulation, as in public performances by trained experts.

The temporal characteristics of mujawwad recitations have not been analyzed and revealed until today. In this study, the reciting of the Egyptian reciters in the form of "mujawwad" is examined. The purpose of this study, is to take the preliminary steps that will allow a comprehensive comparison between the recitings in Egypt, which differ as mujawwad and morattal, which are formed in two categories.

When analyzing the reciting tempo, the most important element of the text that needs to be calculated is the syllable in the $\mathrm{CV}$ pattern. Because the syllable in the $\mathrm{CV}$ pattern is a very important rhythm unit on which the reciting tempo is built and represents the "pulse" element in reciting.

It is seen that some scholars who researched in the fields of music theory, Arabic phonology and Qiraah stated that the ratio of long syllables (CVV-CVC) and short syllables (CV) in Arabic prosody can be expressed with 2 integers. Within the framework of the recitings in Turkiye, we have verified these findings with our previous researches. In this study, the temporal and metric 
character of the recitings of Egyptian reciters will be examined within the framework of reciters such as Abdüssamed, Husari, Minşâvî, Muhammed Rif'at, Mustafa İsmâil and Şa 'şâ̂.. In determining the recitings to be analyzed, it was preferred that they were recited by contemporary reciters who lived in the same period.

The hypothesis of the study was established as "when the Egyptian reciters' recitings in the mujawwad course are analyzed comparatively, it is seen that their temporal characteristics are very similar." Our research has a descriptive character that reveals the temporal and metric features seen in the reciters' performances. In this study, reciters' recitings of Surat al-Fatiha was analyzed with Praat phonetic analysis software.

In this study in which mujawwad tempo type is the subject, first of all, CV unit time averages and associated CV-PM values have calculated. Then, the time averages of the long syllables in the $\mathrm{CVV} / \mathrm{CVC}$ pattern and the short syllables in the CV pattern have been compared to each other and the temporal relationship between the long and short syllables have been revealed.

When the tables containing the $\mathrm{CV}$ unit time averages of the sentences in the recitings, in which the reciters use the mujawwad course, are analyzed, it is seen that the average CV unit time of the recitings is in the range of $0.33-0.43$ seconds. In this interval, it can be said that the recitings of Abdüssamed, Husari, Minşâvî and Şa'şâî are concentrated in the middle of these two values, whereas the recitings of Muhammed Rif'at and Mustafa İsmâil constitute two extreme boundaries.

If we examine the table, which includes CV-PM (number of syllables in CV pattern read in per minute) values, which is the value that shows how many short syllables reciters read in a minute in mujawwad course, it is understood that the recitings vary in a tempo scale between 138 and $185 \mathrm{CV}$ PM. It is also understood from the related tables that the ratio of long syllables to short syllables in the recitings of the Egyptian reciters in the course of mujawwad indicates 2 integers. It is seen that the research hypothesis of this research is largely verifiable.

Keywords: Turkish Religious Music, Egypt, Qur'an, Mujawwad, Tempo, Metro-Rhythmic. 